\title{
Diet of the harbour seal Phoca vitulina: implication for the flatfish nursery in the Bay of Somme (English Channel, France)
}

\author{
Jérôme SPITZ ${ }^{1,2, a}$, Laëtitia DUPUIS ${ }^{3}$, Vanessa BECQUET ${ }^{4}$, Bruno DUBIEF ${ }^{2}$ and Andrew W. TRITES ${ }^{1}$ \\ ${ }^{1}$ Marine Mammal Research Unit, Fisheries Centre, University of British Columbia, 2202 Main Mall, Vancouver, \\ British Columbia V6T 1Z4, Canada \\ 2 Observatoire PELAGIS, Systèmes d'Observation pour la Conservation des Mammifères et Oiseaux marins, UMS 3462, CNRS/Université de \\ La Rochelle, 17071 La Rochelle, France \\ 3 Picardie Nature, 1 rue de Croy, 80000 Amiens, France \\ ${ }^{4}$ Littoral, Environnement et Sociétés, UMR 7266, Université de La Rochelle/CNRS, 2 rue Olympe de Gouges, 17032 La Rochelle \\ Cedex, France
}

Received 26 February 2014; Accepted 3 March 2015

\begin{abstract}
Changes in marine species abundance can impact ecosystems' stability and sustainability of fisheries. In the eastern Atlantic Ocean, harbour seals (Phoca vitulina) are top predator occupying highest trophic level in coastal marine food webs. Although, the overall European population decline, harbour seals have increased dramatically since the 1990's at the southern limit of their European distribution along the French coast of the English Channel. However, little is known about the feeding habits of the expanding peripheral populations limiting the assessment of the role and the impact of this predator in these coastal ecosystems. Here, we investigated the sex-specific diet of harbour seals during summer in the Bay of Somme, the largest colony in the English Channel. We collected 91 faecal samples from haul-out sites mainly used by harbour seal but also by few grey seals. Molecular methods have been used to discard grey seal samples and differentiate gender. Collectively, the 86 faecal samples of harbour seals contained the remains of 3327 prey belonging to at least 13 fish species, and represented $\sim 109 \mathrm{~kg}$ of consumed fish (of which $85 \%$ were soles and plaices). Most of the fish consumed were juvenile and small flatfish (Buglossidium luteum, Microchirus variegatus, Solea vulgaris, Pegusa lascaris, Pleuronectes platessa and Platichthys flesus). Hard-part identification further showed a similar diet between the sexes in terms of primary prey consumed, but a greater diversity of preys in the male diet. The dependence of harbour seals on flatfish has not been reported elsewhere and has significant implications for the sustainability of the important flatfish nursery in the Bay of Somme. Consumption estimation and ecosystem modelling are now required to provide robust assessment of the effect of harbour seal predation on population dynamics of the flatfish nursery, on ecosystem of the Bay of Biscay at-large, and finally on interactions with fisheries.
\end{abstract}

Keywords: Diet / Foraging ecology / Molecular scatology / Sex assignment / Species assignment / Harbour seal / Pinniped

\section{Introduction}

Environmental and human pressures impact on the distribution and abundance of marine species (Cheung et al. 2009); such impacts have effects on biodiversity, ecosystems' stability and sustainability of fisheries (Brander 2007; Pereira et al. 2010). Trophic interactions are often complex within marine food webs, hence important changes occurring on the abundance of one species, either a prey or a predator, induced generally cascading trophic effects affecting different trophic levels of an ecosystem (Pace et al. 1999). For instance, marine top predators influence the structure of prey community (Heithaus et al. 2008), and conversely, variability in prey availability

\footnotetext{
a Corresponding author: jspitz@univ-lr.fr
}

influence the population dynamics of predators (Trites and Donnelly 2003).

Seals are important top predators in marine ecosystems and potentially compete with fisheries (e.g., Gulland 1987; Bowen 1997). Both operational and biological interactions can existed between seals and fisheries (Wickens et al. 1992). Operational conflicts occur during fishing operations when seals directly depredate commercial species in fishing gears or damage fishing equipment. Operational interactions also include injury or mortality due to accidental by-catch or entanglement in fishing gears, or to intentional interactions from fishermen. Biological conflicts include direct competition for shared prey species, indirect competition impacting food web dynamics, dispersal of fish parasites or seal disturbance in sensitive areas. 


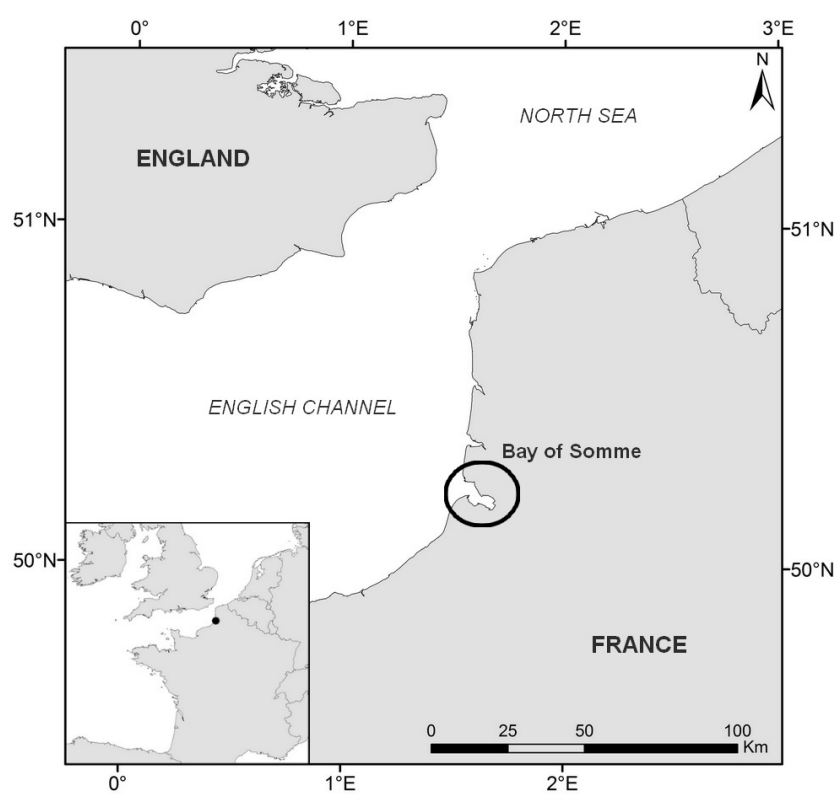

Fig. 1. Study area: location of the Bay of Somme on the French Channel coast.

Harbour seals (Phoca vitulina) in the eastern Atlantic number between 113450-134420 animals (Bjorge et al. 2010) and have a core distribution that stretches from South Scandinavia to Ireland and the United Kingdom. However, their overall numbers have been declining since the 1990's (Wilson and Montgomery-Watson 2002; Lonergan et al. 2007). Food shortage due to overfishing for sandeels in the North Sea and competition with others species, especially grey seals, Halichoerus grypus, is the main suspect cause to explain this decline (Tollit and Thompson 1996; Brown et al. 2001; Sharples et al. 2009). Other possible explanations for the population decline include disturbance, pollution, pathogens and predation by killer whales (Mitchell and Kennedy 1992; Härkönen et al. 2006; Bolt et al. 2009; Hall and Frame 2010).

In contrast to the population declines occurring in their distributional core, harbour seals have been increasing at colonies at the southern limit of their European range along the French coast of the English Channel. Maximum numbers counted along the French coast have increased more than 10-fold from 1990-2008 (Hassani et al. 2010), suggesting a distributional population shift away from the core to the edge of the range.

The largest harbour seal colony in the English Channel is located in the Bay of Somme. This bay is situated on the northwestern coast of France (Fig. 1), and is a large productive macrotidal ecosystem of $70 \mathrm{~km}^{2}$ characterized by large sand banks that are submerged at high tide and used by the seals to haul out at low tide. The numbers of seals residing in the Bay of Somme has risen from $\sim 10$ animals in the early 1990's, to a maximum of 186 in 2008 (Hassani et al. 2010), and 370 in 2012 (Dupuis, unpubl. data). Increasing numbers of grey seals have also become resident to the bay (Dupuis, unpublished data). At the same time, around fifty small fishing units exploit the Bay of Somme from three different harbours: Le Crotoy, Saint-Valérie-sur-Somme and Le Hourdel. The main target fish are sole (Solea solea) and plaice (Pleuronectes platessa) but
Table 1. Sampling of harbour seal scats in the Bay of Somme from 2002 to 2011.

\begin{tabular}{ccccc}
\hline & July & August & October & Total \\
\hline 2002 & & & 1 & 1 \\
2003 & & 3 & & 3 \\
2007 & 3 & 1 & & 4 \\
2008 & 16 & 1 & & 17 \\
2009 & 8 & & & 8 \\
2010 & & 12 & 2 & 14 \\
2011 & 13 & 26 & & 39 \\
\hline Total & 40 & 43 & 3 & 86 \\
\hline
\end{tabular}

detailed fishery statistics including also recreational fishery activities are unavailable at the scale of inshore waters of the Bay of Somme (e.g., Lemoine and Giret 1991; Carpentier et al. 2009). Nevertheless, the Bay of Somme is identified as a major sole and plaice nursery on the Eastern Channel (Riou et al. 2001) and no particular trend appeared affect the exploited fish community in the early 2000's (Rochet et al. 2005).

The aim of our study was to describe the diet of harbour seals in the Bay of Somme. Such quantitative results are central to further evaluate and monitor the effect of harbour seals on the trophic food web of the Bay of Somme including competition with local fisheries. We therefore identified and measured prey remains recovered from faecal samples (scats) of seals collected on sand banks used at low tide during summer. We also conducted molecular analyses to investigate sex differences in diet, and to ensure that the collected scats were from harbour seals and not grey seals.

\section{Materials and methods}

\subsection{Seal species identification from scat collection}

A total of 91 scats were opportunistically collected at haulout sites during summer (Table 1) and stored frozen at $-20{ }^{\circ} \mathrm{C}$ until laboratory analyses. All haul-out sites that are submerged at high tide are sand banks located inside the bay. The precise location of sand banks varied within years.

DNA was extracted from the scats using the NucleoSpin Soil extraction kit (Macherey-Nagel). Briefly, 20-50 mg of faecal material was removed from the outside of the scats and added to a mixture of lysis buffer and beads to improve the lysis. After a brief vortex and incubation $\left(5 \mathrm{~min}, 4^{\circ} \mathrm{C}\right)$, the extract was centrifuged $1 \mathrm{~min}$ at $11000 \mathrm{~g}$ and the supernatant was purified as described by the supplied protocol and eluted in $20 \mu \mathrm{l}$ of elution buffer. Quality and quantity of DNA was checked with a NanoDrop 1000 spectrophotometer (ThermoScientific). To differentiate grey seal from harbour seal samples we adapted the method developed by Masland et al. (2010); 50 to $100 \mathrm{ng}$ of DNA were amplified by PCR in $50 \mu \mathrm{l}$ volume with $1.5 \mathrm{mM} \mathrm{MgCl} 2,10 \mathrm{X}$ aq buffer, $1.5 \mathrm{U}$ Taq DNA Polymerase (VWR), $0.2 \mathrm{mM}$ of each dNTP and $0.2 \mathrm{mM}$ of each primer (PINNL and PINNR described in Masland et al.). Amplification was performed in a TC5000 (Techne) with the following cycling parameters: $95{ }^{\circ} \mathrm{C}$ for $3 \mathrm{~min}$ followed by 35 cycles of $95^{\circ} \mathrm{C}$ for $30 \mathrm{~s}, 56^{\circ} \mathrm{C}$ for $30 \mathrm{~s}$ and $1 \mathrm{~min}$ 


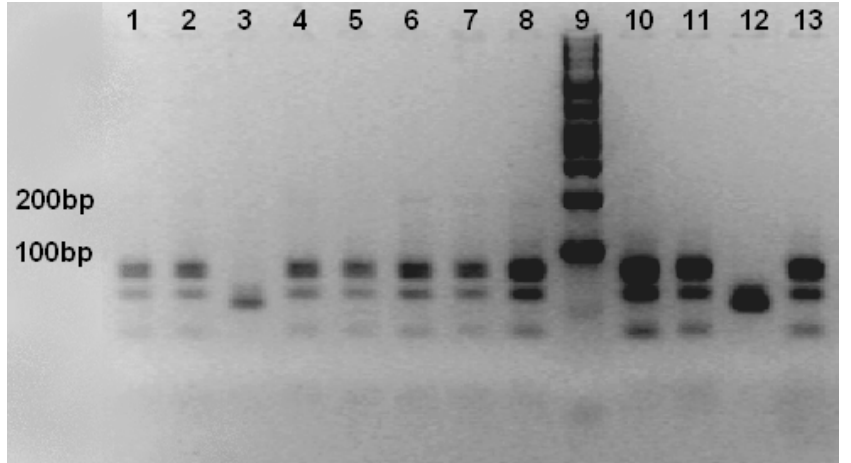

Fig. 2. Electrophoretic 3\% agarose gel of restriction digest of 2 positive controls (known pinniped species) and 10 scat samples (from unknown pinniped species). Lane 9 is 100 bp ladders. Lane 12 is grey seal muscle tissue positive control, and lane 13 is harbour seal muscle tissue positive control. Of the 10 scats samples (lanes 1-8 and 10-11), only lane 3 matches the known grey seal sample (lane 12).

for $72{ }^{\circ} \mathrm{C}$, followed by $72{ }^{\circ} \mathrm{C}$ for $7 \mathrm{~min}$. The amplified portion of mitochondrial $16 \mathrm{~S}$ ribosomal DNA was then digested with the restriction enzyme MluCI (isochizomer of Tsp5091 initially used in Masland et al.) to obtain diagnostic banding patterns. Digestion was performed at $37{ }^{\circ} \mathrm{C}$ for $3.5 \mathrm{~h}$ in $20 \mu \mathrm{l}$ volume with $16 \mu \mathrm{l}$ amplicon, $20 \mathrm{U}$ MluCI enzyme and 10X buffer followed by inactivation of enzyme $20 \mathrm{~min}$ at $80{ }^{\circ} \mathrm{C}$. Digested products were then checked by electrophoresis in a $3 \%$ agarose gel (3:1 Agarose NuSieve, Tebu-bio) $80 \mathrm{~V}$ for $1 \mathrm{~h}$ followed by $100 \mathrm{~V}$ for $2 \mathrm{~h}$ (Fig. 2). Sex was determined by amplification of the conserved region of the $S R Y$ gene according to Reed et al. (1997). Conditions of amplification were the same as those used for species identification.

\subsection{Diet analysis}

Quantification of diet from scat analysis followed procedures generally used for pinnipeds (Pierce and Boyle 1991; Ridoux et al. 2007; Spitz et al. 2010). Scat samples were washed through a $0.2 \mathrm{~mm}$ mesh size sieve to remove prey hard parts (otoliths and bones), which were later identified to species level using available keys and guides (Härkönen 1986; Tuset et al. 2008) as well as our reference material. Some taxonomically close species have similar otoliths which we were unable to differentiate, such as yellow versus thickback soles (Buglossidium luteum and Microchirus variegatus), common versus sand soles (Solea vulgaris and Pegusa lascaris) or within plaice species (Pleuronectes platessa and Platichthys flesus); these twin species have been pooled. Diet composition was quantified by frequency of occurrence (number or proportion of scats containing a given prey taxon), relative abundance (number or proportion by number of individuals belonging to a given prey taxon over all samples) and reconstituted body mass (mass or proportion by mass of a given prey taxon over all samples). A prey species was considered present in a sample when at least one diagnostic part was found. The total number of food items was estimated as the highest number given either by half of paired structures (otoliths, operculum, dentary, premaxillary bones) or total number of impaired structures (parasphenoid). Otoliths were measured following standards (otolith length and otolith width). Otolith measurements were then converted to total body length and individual body mass by using available allometric relationships (Härkönen 1986). The reconstituted mass of each prey taxon represented within each scat sample was estimated by averaging the individual body masses of prey in that sample (based on the size of otoliths) and multiplying this by the number of individuals of the same taxon in the same sample.

Confidence intervals (95\% CI) for the percentages by number and mass were generated for each prey species by bootstrap simulations of sampling errors (Reynolds and Aebischer 1991) written using $R$ (R Development Core Team 2008). Random samples were drawn with replacement, and the procedure was repeated 1000 times. The lower and upper bounds of the $95 \%$ CI were the 25th and 975th values previously ranked in increasing order. Possible biases influencing the reconstituted prey body size related to the digestive erosion of otoliths were not estimated.

\subsection{Dietary overlap between male and female seals}

The dietary overlap $(\mathrm{O})$ between male and female seals in mass and in number was obtained using the Pianka index (Pianka 1974), which ranges from 0 (no overlap) to 1 (complete overlap); values greater than 0.5 are considered to indicate a high overlap. The Pianka index was calculated as follows:

$$
\mathrm{O}=\frac{\sum p_{i A} p_{i B}}{\sqrt{\sum p_{i A}^{2} \sum p_{i B}^{2}}}
$$

where $p_{i A}$ is the percentage by mass or by number of the prey $i$ found in the diet of male seals, and $p_{i B}$ is the percentage by mass or by number of the prey $i$ found in the diet of female seals.

\section{Results}

\subsection{Seal species assignment}

Seal DNA was successfully extracted and amplified in $77 \%$ of samples. Among these 70 scats, only 5 samples $(<7 \%)$ were from grey seals; we attributed the 21 unassigned scats to harbour seal assuming the probability of having grey seal samples is low. Within the harbour seal-designated scats ( $n=86$ scats), the proportion from males was slightly higher (54\%) than females $(46 \%)$.

\subsection{Dominant preys in summer}

The diet of harbour seals in Bay of Somme during summer consisted solely of fish, no cephalopod or large crustaceans were found. A total of 3327 individuals were identified from at least 13 different species of fish. These accounted for a total reconstructed biomass of about $109 \mathrm{~kg}$. However, only flatfish species and dragonets constituted a significant proportion of 
Table 2. Prey found in 86 scats of harbour seals in the Bay of Somme, western channel. $N$ : number of each prey, total mass (g) of each prey, mean value \pm standard deviation, $95 \%$ confidence interval $(\mathrm{CI})$, * species only found in male diet, Und. undetermined.

\begin{tabular}{|c|c|c|c|c|c|c|c|c|c|c|}
\hline \multirow{2}{*}{ Species } & \multirow{2}{*}{$\begin{array}{c}\text { Occurrence } \\
\%\end{array}$} & \multicolumn{3}{|c|}{ Abundance } & \multicolumn{2}{|c|}{ Prey length $(\mathrm{mm})$} & \multicolumn{2}{|c|}{ Prey mass (g) } & \multicolumn{2}{|c|}{ Biomass } \\
\hline & & $N$ & $\% N$ & $95 \% \mathrm{CI}$ & Mean \pm SD & Range & Mean \pm SD & Range & \% Total mass & $95 \% \mathrm{CI}$ \\
\hline $\begin{array}{l}\text { Clupeidae } \\
\text { Sardina pilchardus * } \\
\text { Gadidae }\end{array}$ & 5.1 & 5 & 0.1 & $0-0.3$ & $189 \pm 16$ & $170-207$ & $69 \pm 70$ & $52-95$ & 0.3 & $0-0.6$ \\
\hline Trisopterus spp. * & 1.3 & 1 & 0.0 & $0-0.1$ & 60 & 60 & 3 & 3 & 0.0 & $0-0$ \\
\hline $\begin{array}{l}\text { Und. Gadidae } \\
\text { Belonidae }\end{array}$ & 1.3 & 1 & 0.0 & $0-0.1$ & - & - & - & - & - & - \\
\hline $\begin{array}{l}\text { Belone belone * } \\
\text { Mugilidae }\end{array}$ & 1.3 & 1 & 0.1 & $0-0.1$ & 43 & 43 & 85 & 85 & 0.2 & $0-0.7$ \\
\hline $\begin{array}{l}\text { Und. mullets * } \\
\text { Trachinidae }\end{array}$ & 1.3 & 1 & 0.0 & $0-0.1$ & 464 & 464 & 874 & 874 & 0.8 & $0-2.3$ \\
\hline $\begin{array}{l}\text { Trachinus draco } \\
\text { Ammodytidae }\end{array}$ & 6.4 & 13 & 0.4 & $0-0.8$ & $138 \pm 33$ & $100-201$ & $35 \pm 29$ & $8-102$ & 0.4 & $0.1-0.8$ \\
\hline $\begin{array}{l}\text { Und. sandeels * } \\
\text { Gobidae }\end{array}$ & 2.6 & 50 & 1.5 & $0-4.1$ & $140 \pm 21$ & $95-188$ & $7 \pm 3$ & $2-16$ & 0.3 & $0-0.9$ \\
\hline $\begin{array}{l}\text { Und. gobies } \\
\text { Callionymidae }\end{array}$ & 7.7 & 28 & 0.8 & $0.1-2.3$ & $54 \pm 14$ & $18-76$ & $1 \pm 1$ & $0.1-3.6$ & 0.0 & $0-0.1$ \\
\hline $\begin{array}{l}\text { Callionymus lyra } \\
\text { Soleidae }\end{array}$ & 53.8 & 619 & 18.6 & $10-24.9$ & $140 \pm 31$ & $55-245$ & $21 \pm 16$ & $1-107$ & 11.7 & $5.7-16.7$ \\
\hline $\begin{array}{l}\text { Solea vulgaris / } \\
\text { Pegusa lascaris }\end{array}$ & 60.3 & 384 & 11.5 & $6.9-15.6$ & $191 \pm 49$ & $63-346$ & $77 \pm 62$ & $2-427$ & 27.1 & $18.1-35.9$ \\
\hline $\begin{array}{l}\text { Buglossidium luteum/ } \\
\text { Microchirus variegatus } \\
\text { Pleuronectidae }\end{array}$ & 76.9 & 1621 & 48.6 & $42.1-65.4$ & $140 \pm 29$ & $42-235$ & $26 \pm 17$ & $1-119$ & 38.4 & $31.7-55.2$ \\
\hline $\begin{array}{l}\text { Pleuronectes platessa/ } \\
\text { Platichthys flesus } \\
\text { Scophtalmidae }\end{array}$ & 74.4 & 521 & 15.6 & $7.3-21.4$ & $132 \pm 65$ & $48-343$ & $41 \pm 55$ & $1-432$ & 19.6 & $10.7-25.6$ \\
\hline Scophtalmus spp. & 1.3 & 1 & 0.0 & $0-0.1$ & 139 & 139 & 35 & 35 & 0.0 & $0-0.1$ \\
\hline $\begin{array}{l}\text { Arnoglossus spp./ } \\
\text { Zeugopterus punctatus }\end{array}$ & 33.3 & 75 & 2.2 & $1.4-2.9$ & $103 \pm 19$ & $66-152$ & $16 \pm 9$ & $4-46$ & 1.1 & $0.7-1.5$ \\
\hline Und. flatfish & 2.6 & 2 & 0.1 & $0-0.1$ & - & - & - & - & - & - \\
\hline Und. fish & 7.7 & 9 & 0.3 & $0.1-0.4$ & - & - & - & - & - & - \\
\hline
\end{tabular}

the harbour seal diet, with $97 \%$ of the ingested biomass comprising only four prey types (Table 2).

Soleids were the most dominant prey in the harbour seals' diet. Yellow and thickback soles ranging in size from $4.2-23.5 \mathrm{~cm}$ (Fig. 3) were found in $77 \%$ of samples; they represented $38 \%$ of the reconstructed ingested biomass (\% Mass) and $49 \%$ of the prey relative abundance (\%Number). Common and sand soles $(6.3-35.6 \mathrm{~cm}$, Fig. 2) were the second most important group with $27 \%$ of the ingested biomass, $12 \%$ of the relative abundance and found in $60 \%$ of samples. Plaice $(4.8-$ $34.3 \mathrm{~cm}$ ) were the third most important prey with $19 \%$ of the ingested biomass, $16 \%$ of the relative abundance and found in $74 \%$ of samples. Finally, dragonets Callionymus lyra $(5.5-$ $24.5 \mathrm{~cm}$ ) were the fourth most important prey, reaching $12 \%$ of the ingested biomass $19 \%$ of the relative abundance and found in $54 \%$ of samples.

\subsection{Importance of juvenile fish in the diet of male and female seals}

Harbour seals in the Bay of Somme fed mainly on small fish (average body size $14.5 \pm 4.8 \mathrm{~cm}$ and $57 \pm 87 \mathrm{~g}$ ) that ranged from a $1.8 \mathrm{~cm}(<1 \mathrm{~g})$ goby to a $46.4 \mathrm{~cm}(874 \mathrm{~g})$ mullet.
However, fish $<20 \mathrm{~cm}$ accounted for $92 \%$ of the diet (based on numbers consumed), and individuals $10-18 \mathrm{~cm}$ accounted for $70 \%$ of the diet (Fig. 4).

Sex variations in diet composition appeared to be fairly limited in summer (Fig. 5). Male and female diets were very similar, the dietary overlap, as estimated by the Pianka index, revealed a high degree of overlap in number $(0.85)$ and mass of prey consumed (0.94). Males and females had similar diets in terms of the primary prey consumed, but the diversity of species consumed was higher for males (13 different prey species) than for female ( 9 prey species). Hence, almost all prey species of secondary importance were found in the scats from the male seals. Males also consumed the largest individuals in an array of different prey species.

\section{Discussion}

The Bay of Somme is home to one of the southernmost permanent harbour seal colonies in the north-east Atlantic. The summer diet of harbour seals in this southern portion of their range was dominated by a single prey profile consisting of juvenile and small flatfish. Sole and plaice collectively represented more than $85 \%$ of the consumed biomass. 

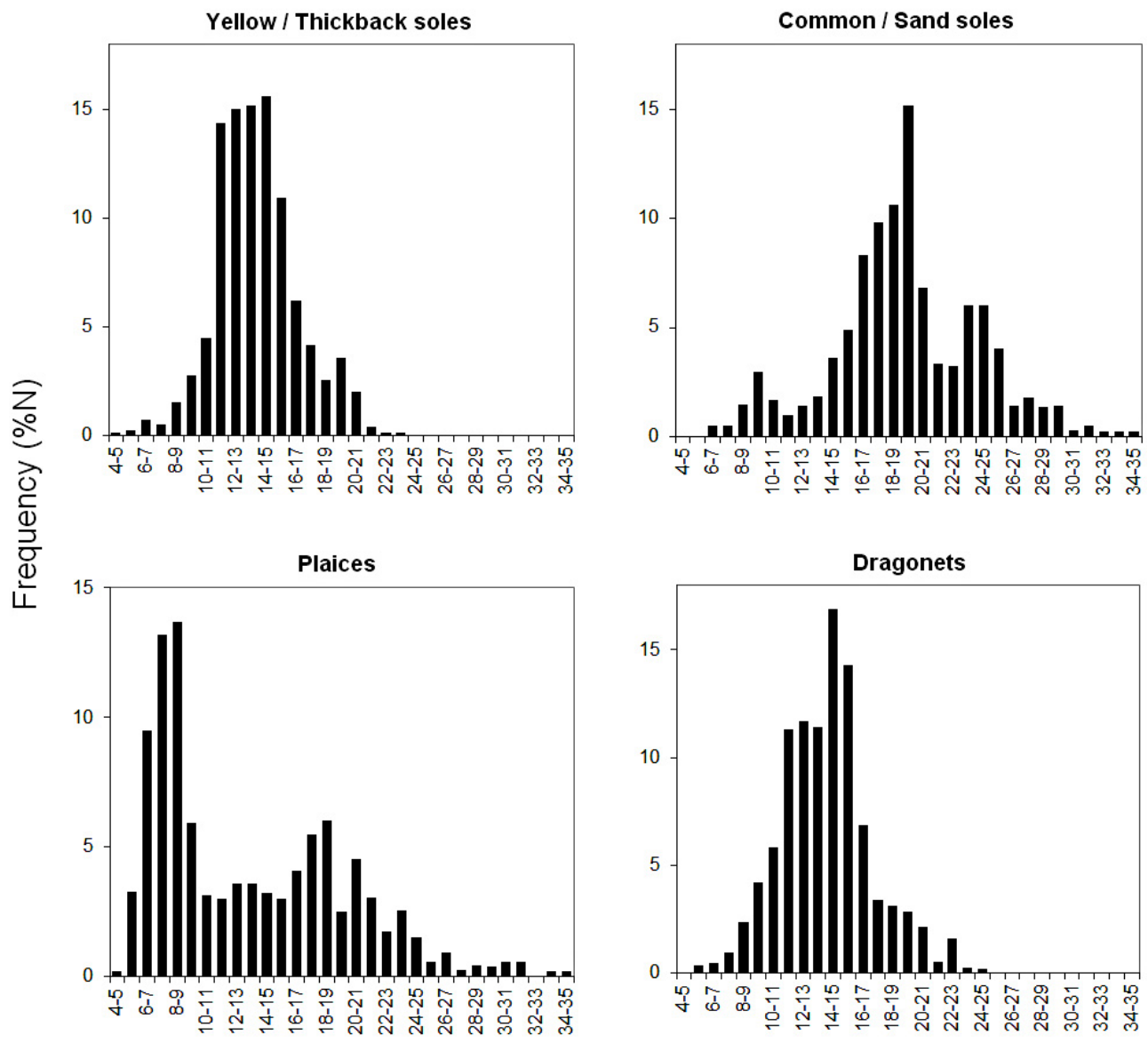

Prey length (cm)

Fig. 3. Size distribution for each primary species consumed by harbour seals in the Bay of Somme: yellow and thickback soles (Buglossidium luteum and Microchirus variegatus), common and sand soles (Solea vulgaris and Pegusa lascaris), plaice (Pleuronectes platessa and Platichthys flesus) and dragonets (Callionymus spp.). Prey lengths were estimated from otolith measurements.

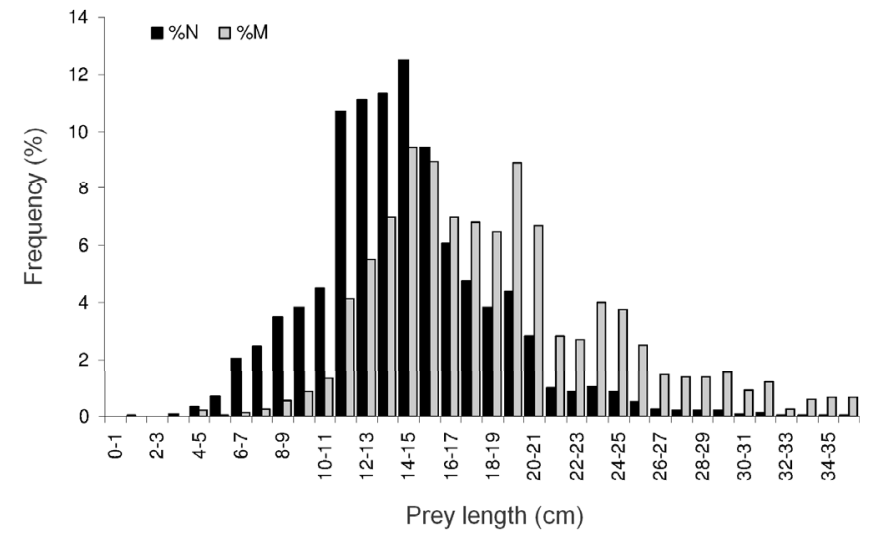

Fig. 4. Size distribution of prey consumed by harbour seals in the Bay of Somme expressed as relative prey abundance for each length class (\%Number, black bars) and relative biomass ingested for each length class (\%Mass, grey bars).

No cephalopod or crustaceans were present, and almost no pelagic species were eaten. Diets were similar between male and female seals. However, seasonal variations can occur in the diets of harbour seals (e.g., Tollit and Thompson 1996; Brown et al. 2001; Vikingsson et al. 2003; Wilson et al. 2002). Our sampling was limited to summer, and harbour seal diet exhibited probably some seasonal variations in the Bay of Somme. Thus, our results should be treated with caution when used for other seasons.

Several methodological limitations are inherent to scat analysis (reviews: Pierce and Boyle 1991; Bowen and Iverson 2013). Firstly, sample sizes can affect the representativeness of diet description using scat analysis. Here, the Bay of Somme seal population is a smaller colony compared to those from the core areas further north, and is characterized by the absence of haul-out sites that can be used by the seals at high tide. Samples must therefore be gathered from tidally washed area, which makes obtaining large collections of scat samples difficult over a realistic period of time. Our sample size was nevertheless comparable to previous studies conducted on small seal colonies (Pierce and Santos 2003; Ridoux et al. 2007; Kavanagh et al. 2010) and appears to describe satisfactory the average summer diet of harbour seal in this colony (Trites and Joy 2005). Secondly, a characteristic of scat samples is that the remains used to describe the diet are made up of digested material, and digestion can cause some biases in the quantification 


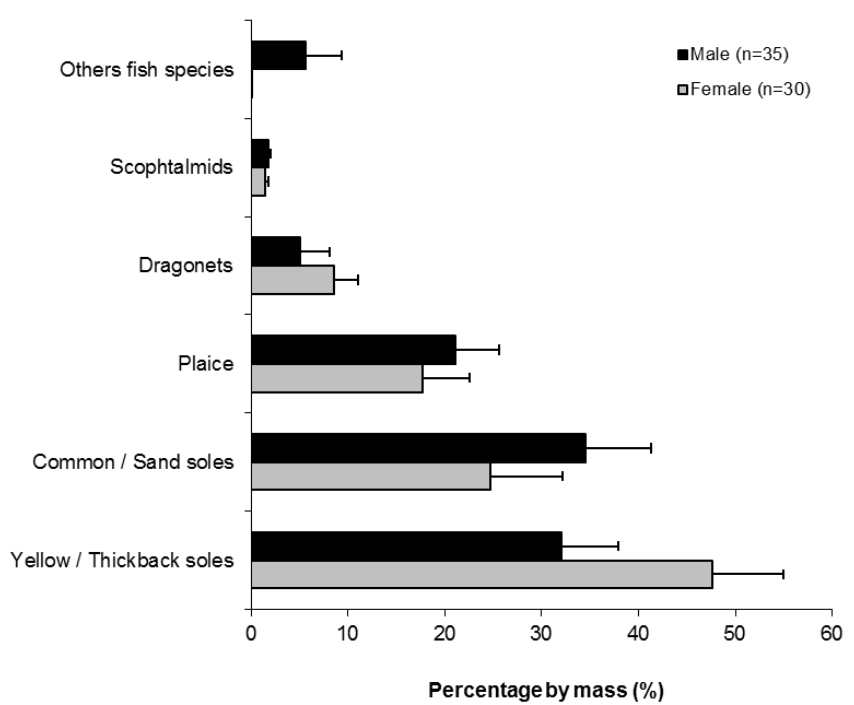

Fig. 5. Variation in the diet of harbour seals in the Bay of Somme between males (black bars) and females (grey bars) in terms of ingested biomass (\%Mass $\pm \mathrm{SD}$ ). Samples sizes $(n)$ indicate the number of scats analysed.

of ingested prey. In our study, all of the scats we collected were fresh, which meant that the species of prey we recovered reflected the feeding activity during the day prior to sampling. Extensive literature has reported on biases associated with prey-specific transit times in the digestive tract and differential erosion of diagnostic parts affecting the numbers and sizes of hard parts recovered in scats, digestion process may impact the probability that a prey eaten is recovered and the ability to back-calculate original prey body size. In a simple way, such biases are evidenced since prey with large hard parts may be overestimated, and on the contrary prey with small hard parts may be underestimated. Moreover, seals have been sometimes observed to feed mostly flesh on very large prey individuals limiting their detection in hard part remains. We fully acknowledge these usual potential biases in scat analysis. Further development of next-generation sequencing to characterize food DNA from scats could in the future allow to obtain more accurate quantification of seals' diet (Thomas et al. 2014).

Keeping the limitations of scat analysis in mind, our data provide the first insights into the feeding ecology of harbour seals from the largest colony along the coast of English Channel at the southern limit of their European distribution. These baseline data contribute to assessing the role of harbour seal in the Bay of Somme ecosystem, including potential interactions with fisheries, and comparisons with other sites within the distributional range of harbour seals.

\subsection{Seal diet variability in Europe}

Diets of harbour seals have been described for many colonies across Europe and have been shown to vary geographically (review: Spitz et al. 2010). Sandeels mostly dominate the diet of the harbour seal in Scotland including Hebrides and Shetland islands (Tollit and Thompson 1996;
Pierce and Santos 2003; Sharples et al. 2009). Gadids mostly prevail elsewhere in Europe (England, Ireland, Denmark Iceland and Norway) in addition to flatfish and/or clupeids (Härkönen 1987; Olsen and Bjørge 1995; Wilson et al. 2002). The wide geographic variation in diet likely reflects the geographic distribution of prey species and the foraging strategy of harbour seals. Harbour seals generally forage year-round within $\sim 10 \mathrm{~km}$ of their haul-out sites (Thompson 1993; Lowry et al. 2001; Vincent et al. 2010). Hence, their diets likely reflect local prey availability.

The three harbour seal colonies located along the French coast of the English Channel (from north to south: Bay of Somme, Bay of Veys and Bay of Mont-Saint-Michel) are at the most southern colonies of its European range. The diet of seals in the Bay of Somme was strikingly different from that of the seals in the nearest colony to them in the Bay of Veys ( $\sim 200 \mathrm{~km}$ away in the English Channel). The two bays are flatfish nurseries and appear to exhibit close adult demersal fish assemblages including flatfish, mullets, gobies, dragonets (e.g., Beillois et al. 1979; Riou et al. 2001; Lorance et al. 2009; Selleslagh et al. 2009). However, diet in the Bay of Veys consisted of large fish and were dominated by mullets ( $49 \%$ of consumed biomass; Spitz et al. 2010). The average body size of prey consumed was $26.2 \mathrm{~cm}$ in the Bay of Veys compared with $14.5 \mathrm{~cm}$ in the Bay of Somme. This difference in dietary specialization likely reflects the use of restricted foraging areas around haul-out sites (Dietz et al. 2013) and the ability of harbour seal to adapt their foraging strategies and diet according to local variations of prey field. It also points to the need to express diets of harbour seals at colony levels rather than at a species level. In addition to difference in local prey availability, the low prey diversity in diet composition within each colony and the high dietary differences among colonies also suggests foraging traditions within harbour seal colonies. Parental and alloparental investments in learning foraging techniques could occur during the lactation period where harbour seal pups go with their mother at sea. Comparatively, female grey seals interact exclusively on land with their pups and adults undertake long foraging trips exhibiting considerable individual dietary specialisation (Vincent et al. 2005; Tucker et al. 2007).

We investigated possible sex-specific differences in the diet of harbour seals. In the Bay of Somme, our study suggested the absence of major sex-specific differences in the diet of harbour seal, a slight increase of prey diversity was suspected for males. Sex-differences in the diets have been reported for several pinniped species such as Steller sea lions (Eumetopias jubatus), South American sea lions (Otaria flavescens) and grey seals (Alonso et al. 2000; Beck et al. 2007; Trites and Calkins 2008). For harbour seal, dietary sex differences have been revealed in north Pacific by analysis of fatty acid signatures in seal blubber, suggesting also a higher prey diversity in the diet of male (Bromaghin et al. 2013). Dimorphism, life-history and foraging strategies or segregation of feeding areas have been proposed to explain these dietary differences.

\subsection{Trophic web implications}

Near-shore waters and estuaries provide many important functions in coastal ecosystems. These areas are extremely 
productive and support important biodiversity (Beck et al. 2001). These near-shore habitats also often serve as nurseries for juvenile fish or invertebrate species, and can consequently be intensively exploited by diverse predator populations, including fish, birds and seals (Leopold et al. 1998; Hiddink et al. 2002). Such top predators (as with fisheries) can induce cascading effects on different trophic levels of an ecosystem and can influence the structure of prey communities (Pace et al. 1999; Heithaus et al. 2008) and the sustainability of fisheries (Brander 2007; Pereira et al. 2010).

The Bay of Somme is a macrotidal ecosystem that supports an important flatfish nursery and high densities of plaices and soles (Riou et al. 2001; Selleslagh et al. 2009). Our results suggest that the colony of harbour seals residing here is dependant on this resource, at least seasonally. However, we were unable to evaluate whether the seals evoke bottom-up effects or top-down forcing within the trophic food webs of the Bay of Somme. Predicting the consequences of changes in flatfish nursery productivity and seal abundance will require understanding the dynamic relationship between harbour seals and juvenile flatfish. Previous ecosystem modelling suggests that the Bay of Somme is an ecosystem that has not yet reached maturity and may be sensitive to possible disturbances (Rybarczyk et al. 2003), such as from the growing seal population. Thus, further studies on the annual prey consumption by harbour seals combined with the dynamics of juvenile flatfish abundance are needed to improve trophic food web analyses of the Bay of Somme, and allow for different management scenarios to be assessed.

\subsection{Potential for conflict with local fisheries}

The recent and rapid increase of the seal population in the Bay of Somme is negatively perceived by local fishermen who largely express their discontent and their concern through the media. Interactions between seals and fisheries are indeed complex and generally hard to disentangle. Seals are often accused of having an economic impact on fisheries by depredating and damaging fishing gears and by reducing the availability of commercial species (Gulland 1987; Butler et al. 2011). Salmon or cod fisheries are the longest history of conflict with local seal populations in Canada or in Scotland where a direct competition for high valued species exists (e.g., Butler et al. 2006; Trzcinski et al. 2006; Lance et al. 2012). Nevertheless, direct effects of marine mammals' predation on the potential catch by fisheries are rare (Morissette et al. 2012). In the Bay of Somme, our results suggested that harbour seals target mostly on species of low or no commercial values or young individuals greatly below the commercial length $(24 \mathrm{~cm}$ for common sole and $27 \mathrm{~cm}$ for plaice; Fig. 3). Hence at present, the potential for direct competition with local inshore fisheries seems limited. Here, our quantitative data on diet composition is the first step to assess the potential interactions between seals and fisheries in the Bay of Somme. Further steps should evaluate the indirect impact of seal consumption by ecosystem modelling, the spatial overlap between local fisheries and seal foraging areas by the use of telemetry data, and the operational interactions (depredation, damage, by-catch) by onboard observations and interview survey of fishermen. Notably, the nature and strength of interactions with fisheries in
Bay of Somme are probably different according to seal species (harbour or grey seals). Hence, factual data are urgently required to provide a robust assessment of biological and operational interactions to solve, or at least reduce, the growing conflict between seals and fishermen along coast of English Channel.

Acknowledgements. We are particularly grateful to all of the volunteers who assisted in collecting seal scats. We also thank the Molecular Core Facility at the University of La Rochelle, and the reviewers for their constructive comments and suggestions. Picardie Nature was supported by the DREAL Picardie, the Conseil Régional de Picardie and the Conseil Général de la Somme. An NSERC (Natural Sciences and Engineering Research Council of Canada) Discovery Grant awarded to Andrew Trites supported part of the study.

\section{References}

Alonso M.K., Crespo E.A., Pedraza S.N., García N.A., Coscarella M.A., 2000, Food habits of the South American sea lion, Otaria flavescens, off Patagonia, Argentina. Fish. Bull. 98, 250-263.

Beck C.A., Iverson S.J., Bowen W., Blanchard W., 2007, Sex differences in grey seal diet reflect seasonal variation in foraging behaviour and reproductive expenditure: evidence from quantitative fatty acid signature analysis. J. Anim. Ecol. 76, 490-502.

Beck M.W., Heck Jr K.L., Able K.W., Childers D.L., Eggleston D.B., Gillanders B.M., Halpern B., Hays C.G., Hoshino K., Minello T.J., 2001, The identification, conservation, and management of estuarine and marine nurseries for fish and invertebrates. BioScience 51, 633-641.

Beillois P., Desaunay Y., Dorel D., Lemoine M., 1979, Nurseries littorales de la baie de Mont Saint Michel et du Contentin Est (ISTPM-EDF n E2302). ISTPM/Ifremer Nantes.

Bjorge A., Desportes G., Waring G.T., Rosing-Asvid A., 2010, Introduction: the harbour seal (Phoca vitulina) - a global perspective. NAMMCO Sci. Publ. 8, 7-14.

Bolt H.E., Harvey P.V., Mandleberg L., Foote A., 2009, Occurrence of killer whales in Scottish inshore waters: temporal and spatial patterns relative to the distribution of declining harbour seal populations. Aquat. Conserv. 19, 671-675.

Bowen W.D., 1997, Role of marine mammals in aquatic ecosystems. Mar. Ecol. Prog. Ser. 158, 267-274.

Bowen W.D., Iverson S.J., 2013, Methods of estimating marine mammal diets: a review of validation experiments and sources of bias and uncertainty. Mar. Mamm. Sci. 29, 719-754.

Brander K.M., 2007, Global fish production and climate change. Proc. Natl. Acad. Sci. USA 104, 19709-19714.

Bromaghin J.F., Lance M.M., Elliott E.W., Jeffries S.J., AcevedoGutierrez A., Kennish J.M., 2013, New insights into the diets of harbor seals (Phoca vitulina) in the Salish Sea revealed by analysis of fatty acid signatures. Fish. Bull. 111, 13-26.

Brown E.G., Pierce G.J., Hislop J.R.G., Santos M., 2001, Interannual variation in the summer diets of harbour seals Phoca vitulina at Mousa, Shetland (UK). J. Mar. Biol. Assoc. UK 81, 325-337.

Butler J.R., Middlemas S.J., Graham I.M., Harris R.N., 2011, Perceptions and costs of seal impacts on Atlantic salmon fisheries in the Moray Firth, Scotland: implications for the adaptive co-management of seal-fishery conflict. Mar. Policy 35, 317-323.

Butler J.R., Middlemas S.J., Graham I.M., Thompson P.M., Armstrong J.D., 2006, Modelling the impacts of removing seal predation from Atlantic salmon, Salmo salar, rivers in Scotland: a tool for targeting conflict resolution. Fish. Manage. Ecol. 13, 285-291. 
Carpentier A., Coppin F., Curet L., Dauvin J.-C., Delavenne J., Dewarumez J.-M., Dupuis L., Foveau A., Garcia C., Gardel L., 2009, Atlas des habitats des ressources marines de la Manche orientale. Charm II, Interreg 3a Progr., Ifremer, Boulogne-sur-mer.

Cheung W.W.L., Lam V.W.Y., Sarmiento J.L., Kearney K., Watson R., Pauly D., 2009, Projecting global marine biodiversity impacts under climate change scenarios. Fish Fish. 10, 235-251.

Dietz R., Teilmann J., Andersen S.M., Rigét F., Olsen M.T., 2013, Movements and site fidelity of harbour seals (Phoca vitulina) in Kattegat, Denmark, with implications for the epidemiology of the phocine distemper virus. ICES J. Mar. Sci. 70, 186-195.

Gulland J.A., 1987. The impact of seals on fisheries. Mar. Policy 11, 196-204.

Hall A.J., Frame E., 2010, Evidence of domoic acid exposure in harbour seals from Scotland: A potential factor in the decline in abundance? Harmful Algae 9, 489-493.

Härkönen T., 1987, Seasonal and regional variations in the feeding habits of the harbour seal, Phoca vitulina, in the Skagerrak and the Kattegat. J. Zool. 213, 535-543.

Härkönen T., Dietz R., Reijnders P., Teilmann J., Harding K., Hall A., Brasseur S., Siebert U., Goodman S.J., Jepson P.D., Rasmussen T.D., Thompson P.M., 2006, A review of the 1988 and 2002 phocine distemper virus epidemics in European harbour seals. Dis. Aquat. Org. 68, 115-130.

Härkönen T.J., 1986, Guide to the otoliths of the bony fishes of the northeast Atlantic, Danbiu, Aps. edn. Denmark.

Hassani S., Dupuis L., Elder J.F., Caillot E., Gautier G., Hemon A., Lair J.M., Haelters J., 2010, A note on harbour seal (Phoca vitulina) distribution and abundance in France and Belgium. NAMMCO Sci. Publ. 8, 107-116.

Heithaus M.R., Frid A., Wirsing A.J., Worm B., 2008, Predicting ecological consequences of marine top predator declines. Trends Ecol. Evol. 23, 202-210.

Hiddink J.G., Troost K., Wolff W.J., 2002, Predation on 0-group and older year classes of the bivalve Macoma balthica: interaction of size selection and intertidal distribution of epibenthic predators. J. Exp. Mar. Biol. Ecol. 269, 223-248.

Kavanagh A.S., Cronin, M.A., Walton, M., Rogan E., 2010, Diet of the harbour seal (Phoca vitulina vitulina) in the west and southwest of Ireland. J. Mar. Biol. Assoc. UK 90, 1517-1527.

Lance M.M., Chang W.-Y., Jeffries S.J., Pearson S.F., AcevedoGutiérrez A., 2012, Harbor seal diet in northern Puget Sound: implications for the recovery of depressed fish stocks. Mar. Ecol. Prog. Ser. 464, 257-271.

Lemoine M., Giret M., 1991, Les pêches artisanales de la Manche orientale. Flottilles et ressources halieutiques. Ifremer Brest.

Leopold M.F., van Damme C.J.G., van der Veer H.W., 1998, Diet of cormorants and the impact of cormorant predation on juvenile flatfish in the Dutch Wadden Sea. J. Sea Res. 40, 93-107.

Lonergan M., Duck C.D., Thompson D., Mackey B.L., Cunningham L., Boyd I.L., 2007, Using sparse survey data to investigate the declining abundance of British harbour seals. J. Zool. 271, 261269.

Lorance P., Bertrand J.A., Brind'Amour A., Rochet M.-J., Trenkel V.M., 2009, Assessment of impacts from human activities on ecosystem components in the Bay of Biscay in the early 1990s. Aquat. Living Resour. 22, 409-431.

Lowry L.F., Frost K.J., Hoep J.M., Delong R.A., 2001, Movements of satellite-tagged subadult and adult harbor seals in Prince William Sound, Alaska. Mar. Mamm. Sci. 17, 835-861.

Masland E.D.P., Sweezy M.A., Ono K.A., 2010, Molecular methods for differentiating grey seal (Halichoerus grypus) and harbour seal (Phoca vitulina) scat. Mol. Ecol. Res. 10, 214-217.
Morissette L., Christensen V., Pauly D., 2012, Marine mammal impacts in exploited ecosystems: would large scale culling benefit fisheries? PloS One 7, e43966.

Mitchell S.H., Kennedy S., 1992, Tissue concentrations of organochlorine compounds in common seals from the coast of Northern Ireland. Sci. Tot. Environ. 115, 163-177.

Olsen M., Bjørge A., 1995, Seasonal and regional variations in the diet of harbour seal in Norwegian waters. In: Blix A.S., Walløe L., Ulltang $\varnothing$. (eds.) Whales, seals, fish and man. Elsevier, Amsterdam, pp. 271-285.

Pace M.L., Cole J.J., Carpenter S.R., Kitchell J.F., 1999, Trophic cascades revealed in diverse ecosystems. Trends Ecol. Evol. 14, 483488.

Pereira H.M., Leadley P.W., Proença V., Alkemade R., Scharlemann J.P., Fernandez-Manjarrés J.F., Araújo M.B., Balvanera P., Biggs R., Cheung W.W., 2010, Scenarios for global biodiversity in the 21 st century. Science 330, 1496.

Pianka E.R., 1974, Niche overlap and diffuse competition. Proc. Natl. Acad. Sci. USA 71, 2141-2145.

Pierce G.J., Boyle P.R., 1991, A review of methods for diet analysis in piscivorous marine mammals. Oceanogr. Mar. Biol. 29, 409-486.

Pierce G.J., Santos M.B., 2003, Diet of harbour seals (Phoca vitulina) in Mull and Skye (Inner Hebrides, western Scotland). J. Mar. Biol. Assoc. UK 83, 647-650.

R Development Core Team, 2008, R: a language and environment for statistical computing, R Foundation for Statistical Computing Vienna Austria, ISBN 3-900051-07-0.

Reed J.Z., Tollit D.J., Thompson P.M., Amos W., 1997, Molecular scatology: the use of molecular genetic analysis to assign species, sex and individual identity to seal faeces. Mol. Ecol. 6, 225-234.

Reynolds J.C., Aebischer N.J., 1991, Comparison and quantification of carnivore diet by faecal analysis: a critique, with recommendations, based on a study of the fox Vulpes vulpes. Mamm. Rev. $21,97-122$.

Ridoux V., Spitz J., Vincent C., Walton M.J., 2007, Grey seal diet at the southern limit of its European distribution: combining dietary analyses and fatty acid profiles. J. Mar. Biol. Assoc. UK 87, 255264.

Riou P., Le Pape O., Rogers S.I., 2001, Relative contributions of different sole and plaice nurseries to the adult population in the Eastern Channel: application of a combined method using generalized linear models and a geographic information system. Aquat. Living Resour. 14, 125-135.

Rochet M.-J., Trenkel V., Bellail R., Coppin F., Le Pape O., Mahé J.-C., Morin J., Poulard J.-C., Schlaich I., Souplet A., 2005, Combining indicator trends to assess ongoing changes in exploited fish communities: diagnostic of communities off the coasts of France. ICES J. Mar. Sci. 62, 1647-1664.

Rybarczyk H., Elkaim B., Ochs L., Loquet N., 2003, Analysis of the trophic network of a macrotidal ecosystem: the Bay of Somme (Eastern Channel). Estuar. Coast. Shelf Sci. 58, 405-421.

Selleslagh J., Amara R., Laffargue P., Lesourd S., Lepage M., Girardin M., 2009, Fish composition and assemblage structure in three Eastern English Channel macrotidal estuaries: a comparison with other French estuaries. Estuar. Coast. Shelf Sci. 81, 149-159.

Sharples R.J., Arrizabalaga B., Hammond P.S., 2009, Seals, sandeels and salmon: diet of harbour seals in St. Andrews Bay and the Tay Estuary, southeast Scotland. Mar. Ecol. Prog. Ser. 390, 265-276.

Spitz J., Mariotti L., Caillot E., Ridoux V., Elder J.F., 2010, The diet of harbour seals (Phoca vitulina) at the southern limit of its European distribution (Normandy, France). NAMMCO Sci. Publ. 8, 313-328. 
Thomas A.C., Jarman S.N., Haman K.H., Trites A.W., Deagle B.E., 2014, Improving accuracy of DNA diet estimates using food tissue control materials and an evaluation of proxies for digestion bias. Mol. Ecol. 23, 3706-3718.

Thompson P.M., 1993, Harbour seal movement patterns. In: Boyd (ed.) Marine mammals. Advances in behavioural and population biology. Symp. Zool. Soc. London, pp. 225-239.

Tollit D.J., Thompson P.M., 1996, Seasonal and between-year variations in the diet of harbour seals in the Moray Firth, Scotland. Can. J. Zool. 74, 1110-1121.

Trites A.W., Calkins D.G., 2008, Diets of mature male and female Steller sea lions (Eumetopias jubatus) differ and cannot be used as proxies for each other. Aquat. Mamm. 34, 25-34.

Trites A.W., Donnelly C.P., 2003, The decline of Steller sea lions Eumetopias jubatus in Alaska: a review of the nutritional stress hypothesis. Mamm. Rev. 33, 3-28.

Trites A.W., Joy R., 2005, Dietary analysis from fecal samples: how many scats are enough? J. Mammal. 86, 704-712.

Trzcinski M.K., Mohn R., Bowen W.D., 2006, Continued decline of an Atlantic cod population: how important is gray seal predation? Ecol. Appl. 16, 2276-2292.

Tucker S., Bowen W.D., Iverson S.J., 2007, Dimensions of diet segregation in grey seals Halichoerus grypus revealed through stable isotopes of carbon $(\delta 13 \mathrm{C})$ and nitrogen $(\delta 15 \mathrm{~N})$. Mar. Ecol. Prog. Ser. 339, 271-282.
Tuset V.M., Lombarte A., Assis C.A., 2008, Otolith atlas for the western Mediterranean, north and central eastern Atlantic. Scient. Mar. 72, 7-198.

Vikingsson G.A., Olafsdottir D., Sigurjónsson J., 2003, Geographical and seasonal variation in the diet of harbour porpoises (Phocoena phocoena) in Icelandic coastal waters. NAMMCO Sci. Publ. 5, 243-270.

Vincent C., Fedak M.A., McConnell B.J., Meynier L., Saint-Jean C., Ridoux V., 2005, Status and conservation of the grey seal, Halichorus grypus, in France. Biol. Conserv. 126, 62-73.

Vincent C., McConnell B.J., Elder J.F., Ridoux V., 2010, Winter habitat use of harbour seals (Phoca vitulina) fitted with Fastloc ${ }^{\mathrm{TM}}$ GPS/GSM tags in two tidal bays in France. NAMMCO Sci. Publ. 8, 285-302.

Wickens P.A., Japp D.W., Shelton P.A., Kriel F., Goosen P.C., Rose B., Augustyn C.J., Bross C.A.R., Penney A.J., Krohn R.G., 1992, Seals and fisheries in South Africa - competition and conflict. S. Afr. J. Mar. Sci. 12, 773-789.

Wilson K., Lance M., Jeffries S., Acevedo-Gutiérrez A., 2014, Finescale variability in harbor seal foraging behavior. PloS One 9, e92838.

Wilson S.C., Montgomery-Watson J., 2002, Recent changes in the pattern of harbour seal pupping in County Down, north-east Ireland. Irish Nat. J. 89-100.

Wilson S.C., Pierce G.J., Higgins C.M., Armstrong M.J., 2002, Diet of the harbour seals Phoca vitulina of Dundrum Bay, north-east Ireland. J. Mar. Biol. Assoc. UK 82, 1009-1018. 